Available online at

ScienceDirect

www.sciencedirect.com
Elsevier Masson France

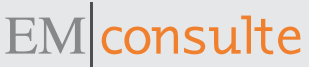

www.em-consulte.com

\title{
In vitro susceptibility of filamentous fungi from mycotic keratitis to azole drugs
}

\section{Sensibilité in vitro aux azolés de champignons filamenteux, agents de kératite fongique}

\author{
C.S. Shobana ${ }^{a, *}$, A. Mythili ${ }^{a}$, M. Homa ${ }^{b}$, L. Galgóczy ${ }^{\text {b }}$, \\ R. Priya ${ }^{a}$, Y.R. Babu Singh ${ }^{a}$, K. Panneerselvam ${ }^{c}$, \\ C. Vágvölgyi $^{\mathrm{b}}$, L. Kredics ${ }^{\mathrm{b}}$, V. Narendran ${ }^{\mathrm{d}}$, P. Manikandan ${ }^{\mathrm{d}, \mathrm{e}}$
}

\footnotetext{
${ }^{a}$ Department of Microbiology, Dr. G.R. Damodaran College of Science, Avanashi Road, Civil Aerodrome Post, Coimbatore, 641 014, Tamilnadu, India

${ }^{\mathrm{b}}$ Faculty of Science and Informatics, Department of Microbiology, University of Szeged, Szeged, Hungary

' Department of Microbiology, MR Government Arts College, Mannargudi, 614 001, Tamilnadu, India

${ }^{\mathrm{d}}$ Department of Microbiology, Aravind Eye Hospital and Post-Graduate institute of Ophthalmology, Coimbatore, 641 014, Tamilnadu, India

e Department of Medical Laboratory, Applied Medical Sciences College, Majmaah University, Saudi Arabia
}

Received 25 June 2014; received in revised form 29 September 2014; accepted 20 October 2014

\section{KEYWORDS}

Mycotic keratitis;

Fungal isolates;

Antifungal susceptibility

and azole drugs

\begin{abstract}
Summary
Objective. - The in vitro antifungal activities of azole drugs viz., itraconazole, voriconazole, ketoconazole, econazole and clotrimazole were investigated in order to evaluate their efficacy against filamentous fungi isolated from mycotic keratitis.

Methods. - The specimen collection was carried out from fungal keratitis patients attending Aravind eye hospital and Post-graduate institute of ophthalmology, Coimbatore, India and was subsequently processed for the isolation of fungi. The dilutions of antifungal drugs were prepared in RPMI 1640 medium. Minimum inhibitory concentrations (MICs) were determined and $\mathrm{MIC}_{50}$ and $\mathrm{MIC}_{90}$ were calculated for each drug tested.

Results. - A total of 60 fungal isolates were identified as Fusarium spp. $(n=30)$, non-sporulating moulds $(n=9)$, Aspergillus flavus $(n=6)$, Bipolaris spp. $(n=6)$, Exserohilum spp. $(n=4)$, Curvularia spp. $(n=3)$, Alternaria spp. $(n=1)$ and Exophiala spp. $(n=1)$. The MICs of ketoconazole, clotrimazole, voriconazole, econazole and itraconazole for all the fungal isolates ranged between $16 \mu \mathrm{g} / \mathrm{mL}$ and $0.03 \mu \mathrm{g} / \mathrm{mL}, 4 \mu \mathrm{g} / \mathrm{mL}$ and $0.015 \mu \mathrm{g} / \mathrm{mL}, 8 \mu \mathrm{g} / \mathrm{mL}$ and $0.015 \mu \mathrm{g} / \mathrm{mL}, 8 \mu \mathrm{g} / \mathrm{mL}$
\end{abstract}

\footnotetext{
* Corresponding author.

E-mail address: shobanasenthilkumar@gmail.com (C.S. Shobana).
} 


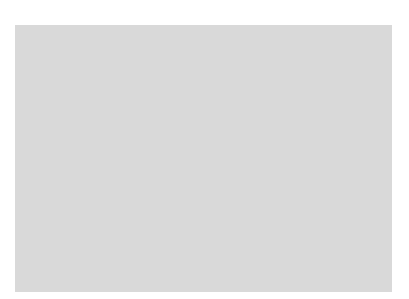

\section{MOTS CLÉS \\ Kératite mycosique ; Sensibilité aux antifongique ; Médicaments azolés}

and $0.015 \mu \mathrm{g} / \mathrm{mL}$ and $32 \mu \mathrm{g} / \mathrm{mL}$ and $0.06 \mu \mathrm{g} / \mathrm{mL}$ respectively. From the $\mathrm{MIC}_{50}$ and $\mathrm{MIC}_{90}$ values, it could be deciphered that in the present study, clotrimazole was more active against the test isolates at lower concentrations $(0.12-5 \mu \mathrm{g} / \mathrm{mL})$ when compared to other drugs tested.

Conclusion. - The results suggest that amongst the tested azole drugs, clotrimazole followed by voriconazole and econazole had lower MICs against moulds isolated from mycotic keratitis.

(C) 2014 Elsevier Masson SAS. All rights reserved.

\begin{abstract}
Résumé
Objectif. - L'activité antifongique in vitro des azolés à savoir, l'itraconazole, le voriconazole, le kétoconazole, l'éconazole et le clotrimazole a été étudiée afin d'évaluer leur efficacité vis-à-vis des champignons filamenteux isolés de kératite mycosique.

Méthodes. - Les échantillons provenant de patients consultant pour kératite fongique au Aravind Eye Hospital et au Post-Graduate Institute of Ophthalmology, Coimbatore, en Inde ont été mis en culture pour recherche de champignons. Les dilutions des antifongiques ont été réalisées en RPMI 1640. Les concentrations minimales inhibitrices (CMI) ont été déterminées et les $\mathrm{CMI}_{50}$ et $\mathrm{CMI}_{90}$ ont été calculées pour chaque antifongique étudié.

Résultats. - Soixante souches de champignons ont été isolées: Fusarium spp. $(n=30)$, moisissures ne fructifiant pas $(n=9)$, Aspergillus flavus $(n=6)$, Bipolaris spp. $(n=6)$, Exserohilum spp. $(n=4)$, Curvularia spp. $(n=3)$, Alternaria spp. $(n=1)$ et Exophiala spp. $(n=1)$. Les CMI du kétoconazole, du clotrimazole, du voriconazole, de l'itraconazole et de l'éconazole vis-à-vis de l'ensemble des isolats fongiques variaient respectivement entre $16 \mu \mathrm{g} / \mathrm{mL}$ et $0,03 \mu \mathrm{g} / \mathrm{mL}, 4 \mu \mathrm{g}$ / $\mathrm{mL}$ et $0,015 \mu \mathrm{g} / \mathrm{mL}, 8 \mu \mathrm{g} / \mathrm{mL}$ et $0,015 \mu \mathrm{g} / \mathrm{mL}, 8 \mu \mathrm{g} / \mathrm{mL}$ et $0,015 \mu \mathrm{g} / \mathrm{mL}$ et $32 \mu \mathrm{g} / \mathrm{mL}$ et $0,06 \mu \mathrm{g} /$ $\mathrm{mL}$. À partir des valeurs des $\mathrm{CMI}_{50}$ et $\mathrm{CMl}_{90}$ que nous avons obtenues, le clotrimazole serait la molécule la plus active vis-à-vis des isolats étudiés, avec des concentrations $(0,12 \mathrm{à} 5 \mu \mathrm{g} / \mathrm{mL})$ plus faibles que celles des autres antifongiques testés.

Conclusion. - Les résultats suggèrent que, parmi les antifongiques azolés testés, le clotrimazole suivi par le voriconazole et l'éconazole avaient les CMI les plus basses vis-à-vis des moisissures isolées de kératites mycosiques.
\end{abstract}

(C) 2014 Elsevier Masson SAS. Tous droits réservés.

\section{Introduction}

Microbial keratitis is the most common severe ocular infection and may be caused by a variety of bacteria, fungi (yeasts, moulds and microsporidia) and protists (e.g. Acanthamoeba). It is characterized by an acute or sub-acute onset of pain, conjunctival injection and corneal ulceration with a stromal inflammatory infiltrate $[42,16,6,36]$. Keratitis due to filamentous fungi is believed to usually occur following trauma, the key-predisposing factor, in healthy young males engaged in agricultural or other outdoor work [8]. The traumatizing agents can be of plant or animal origin (even dust particles), that either directly implant fungal conidia in the corneal stroma, or abrade the epithelium-permitting invasion by exogenous fungi [41]. The etiologic agents of mycotic keratitis show a varying pattern with respect to geographic locality and climatic conditions [7]. More than 105 species of fungi spanning 70 genera have been reported to cause mycotic keratitis [1]. Of these, Fusarium spp. and Aspergillus spp. are the most common etiological agents of corneal ulcerations $[2,5,28]$.

Pujol et al. [32] reported that amphotericin $B(A M B)$ is probably the most effective drug in vivo, although there have been many clinical treatment failures. Natamycin, a tetraene polyene, has long been considered the mainstay of treatment for filamentous fungal keratitis. Although these drugs have poor ocular penetration, they have primarily been useful in cases with superficial corneal infection [29]. Azoles (imidazoles and triazoles) viz., ketoconazole (KTZ), miconazole (MCZ), fluconazole (FLZ), itraconazole (ITC), econazole (ECN) and clotrimazole (CLT), inhibit fungal ergosterol biosynthesis at low concentrations, while at higher concentrations they appear to cause direct damage to the fungal cell walls [40]. According to Srinivasan [35], ongoing research towards rapid diagnosis and specific drug therapy could minimize the morbidity caused by this preventable disease. The current knowledge on antifungal susceptibilities is mainly based on Western literature and local data available in India pertaining to filamentous fungi other than Fusarium and Aspergillus are inadequate. The present study was undertaken to isolate and identify filamentous fungi involved in mycotic keratitis from the patients attending a tertiary care eye hospital in Coimbatore, Tamilnadu, India, and to determine their in vitro susceptibility against five azole antifungal drugs by employing the Clinical and laboratory standards institute (CLSI) broth microdilution method M38A2 document [9].

\section{Materials and methods}

\section{Samples and fungal isolates}

This non-randomized study was carried out at Aravind eye hospital and Post-graduate institute of ophthalmology, Coimbatore, India. The specimen collection was carried out between October 2012 and August 2013. Corneal scrapings were 
performed under aseptic conditions on each ulcer using a flame sterilized Kimura's spatula, after instillation of $4 \%$ preservative free lignocaine (lidocaine) [18]. Material obtained from scraping the leading edge and the base of the ulcer was inoculated directly onto 5\% sheep's blood agar (SBA), chocolate agar (CA) and potato dextrose agar (PDA) (250 g of potato slices, $15 \mathrm{~g}$ agar, $10 \mathrm{~g}$ dextrose and $1000 \mathrm{~mL}$ distilled water), as well as into brain heart infusion (BHI) broth without gentamicin sulphate. SBA base, CA plates and BHI broth were purchased from Himedia Laboratories, Mumbai, India. Plates were incubated under aerobic conditions at $37^{\circ} \mathrm{C}$, while the PDA bottles were incubated at $27^{\circ} \mathrm{C}$ for fungal growth, for $72 \mathrm{~h}$. The obtained material was subjected to Gram staining and $10 \%$ potassium hydroxide mount. Any positive fungal isolate was identified to the genus level and Aspergillus spp. were identified to the species level based on colony morphology and lactophenol cotton blue mount preparation of the fungal cultures employing the cellophane tape flag method $[3,14,24]$.

\section{In vitro azole susceptibility testing}

As per the CLSI guidelines, in every batch of MIC, $A$. flavus ATCC 204304 was included as reference strain [9]. All the fungal isolates were subcultured on SDA plates and incubated at $30{ }^{\circ} \mathrm{C}$ for 7 to 15 days. The inoculum suspension was prepared by harvesting the spores from mature plates into sterile distilled water. The spore suspension was then adjusted spectrophotometrically to the required optical density for each species as outlined in CLSI M38-A2 document [9], providing an inoculum concentration of $0.4 \times 10^{4}$ to $5 \times 10^{4}$ $\mathrm{CFU} / \mathrm{mL}$, which was verified by colony count. Further dilutions (1:50) were carried out using RPMI 1640 medium (Sigma-Aldrich, St. Louis, MO, USA).

The clinically used and commercially available azole drugs viz., ITC (Sigma-Aldrich, St. Louis, MO, USA), voriconazole (VRC) (Aurolab, Madurai, India), KTZ (Himedia, Mumbai, India), ECN (Aurolab, Madurai, India) and CLT (Aurolab, Madurai, India) were chosen for the present study. The drugs were dissolved in dimethyl sulfoxide and the dilutions were prepared in RPMI 1640 in order to achieve a range of 8-0.015 $\mu \mathrm{g} / \mathrm{mL}$ (ECN, VRC and CLT), 32-0.06 $\mu \mathrm{g} / \mathrm{mL}$ (ITC) and $16-0.03 \mu \mathrm{g} / \mathrm{mL}$ (KTZ).

For the broth microdilution method, $100 \mu \mathrm{L}$ of each drug dilution and $100 \mu \mathrm{L}$ of the prepared spore suspension were added into $U$-bottomed microtiter plate wells. Two separate wells were maintained, one as growth control ( $100 \mu \mathrm{L}$ media and $100 \mu \mathrm{L}$ inoculum) and another as sterility control (100 $\mu \mathrm{L}$ media and $100 \mu \mathrm{L}$ water). The plates were incubated at $28^{\circ} \mathrm{C}$ until growth was visible in growth control. MICs were determined visually with the aid of a reading mirror and were defined as the lowest drug concentration that caused $80 \%$ inhibition of the growth in comparison to the growth control. The $\mathrm{MIC}_{50}$ was taken as the MIC that was the median value and similarly, the $\mathrm{MIC}_{90}$ was the 90 th percentile value and represented the concentration of drug that would inhibit $90 \%$ of the isolates tested [10].

\section{Results and discussion}

Of 108 ocular samples that were processed, a total of 48 isolates of bacteria and 60 isolates of filamentous fungi were obtained. Each of the positive samples $(n=60)$ grew only one mold and mixed infections were not obtained. These filamentous fungal isolates were identified as Fusarium spp. $(n=30)$, non-sporulating moulds $(n=9)$, Aspergillus flavus $(n=6)$, Bipolaris spp. $(n=6)$, Exserohilum spp. $(n=4)$, Curvularia spp. $(n=3)$, Alternaria spp. $(n=1)$, and Exophiala spp. $(n=1)$. In the present study, the common aetiological agents of corneal ulcers were identified as filamentous fungi rather than bacteria. Similar results were obtained by Bharathi et al. [6], Manikandan et al. [24] and Homa et al. [15] in South India. Leck et al. [22] also reported similar results from South, North and East India. But other studies from Thailand and Malaysia reported that the most frequent causative agents of microbial keratitis were bacteria [34,27].

Many studies reported that among the filamentous fungi, Fusarium and Aspergillus species were identified as most common corneal pathogens $[23,39,37,33]$. The present study showed that $50 \%$ of corneal infections were caused by Fusarium spp., whereas Aspergillus spp. were responsible for only $10 \%$ of fungal corneal infections. Dematiaceous fungi such as Bipolaris spp., Exserohilum spp., Curvularia spp., Alternaria spp. and Exophiala spp. were also isolated in the present study. Similar incidences of dematiaceous fungal keratitis have been reported previously $[23,39,11]$. Nine $(15 \%)$ of the obtained 60 fungal isolates were not identifiable owing to lack of sporulation. Similar to our findings, Srinivasan et al. [37] revealed that out of 155 fungal isolates cultured from 154 corneal ulcers, 47.1\% were Fusarium spp., $16.1 \%$ were Aspergillus spp., and the remaining organisms were a diverse mixture of unusual fungal pathogens including a large number of unidentified dematiaceous (13.5\%) and hyaline $(9.6 \%)$ fungal species.

The commonly used antifungal medications in the treatment of fungal keratitis include polyenes (natamycin and AMB) and azoles (KTZ, FLZ, ITC and ECN). However, it is difficult to widely use topical natamycin due to its high price [43]. Fusarium and Aspergillus strains are quite sensitive to $A M B$, but poor penetration into corneas and obvious simulative symptoms make its topical preparation unsuitable to be administered with a large dosage and for a long-time [43]. Azoles, most commonly FLZ and ITC [4,21] are often chosen as the combined medications to reduce the toxicity and side effects of $A M B$.

The $\mathrm{MIC}_{50}$ and $\mathrm{MIC}_{90}$ of the azole drugs tested for various fungal isolates are shown in Table 1. CLT was the most effective antifungal drug against all the isolates tested except for the NSM, for which ITC was notably active. CLT was the only drug that was most active against $(1-4 \mu \mathrm{g} / \mathrm{mL})$ fusaria. VRC, ECN and CLT $(0.015-0.5 \mu \mathrm{g} / \mathrm{mL})$ followed by ITC $(0.25-0.5 \mu \mathrm{g} / \mathrm{mL})$ were more promising against $A$. flavus isolates. Bipolaris isolates were inhibited effectively by certain concentrations of CLT and ECN in the range of $0.125-1 \mu \mathrm{g} / \mathrm{mL}$. Exserohilum isolates were inhibited by CLT and VRC in the concentration range of $0.03-2 \mu \mathrm{g} / \mathrm{mL}$. In comparison with other drugs, VRC and CLT showed the lowest MIC range $(0.125-0.25 \mu \mathrm{g} / \mathrm{mL})$ for Curvularia isolates.

The ability to inhibit fungal isolates at such low concentration shows that CLT could be used in the first-line therapy of mycotic keratitis. However, Manikandan et al. [24] reported the requirement of a higher concentration of CLT against Aspergillus spp. compared to the present study. It is notable 
Table 1 In vitro susceptibility of filamentous fungi isolated from keratomycosis to azole drugs. Sensibilité in vitro des champignons filamenteux isolés de kératomycose aux médicaments azolés.

\begin{tabular}{|c|c|c|c|c|c|}
\hline Agents & Groups & $\begin{array}{l}\text { MIC range } \\
(\mu g / m L)\end{array}$ & $\begin{array}{l}\mathrm{MIC}_{50}{ }^{\mathrm{b}} \\
(\mu \mathrm{g} / \mathrm{mL})\end{array}$ & $\begin{array}{l}M \mathrm{MIC}_{90}{ }^{\mathrm{c}} \\
(\mu \mathrm{g} / \mathrm{mL})\end{array}$ & $\begin{array}{l}\mathrm{GM}^{\mathrm{d}} \\
(\mu \mathrm{g} / \mathrm{mL})\end{array}$ \\
\hline \multirow[t]{8}{*}{ CLT } & Fusarium spp. & $1-4$ & 4 & 4 & 3.134 \\
\hline & Non-sporulating molds & $0.25-4$ & 1 & 2 & 1.166 \\
\hline & Aspergillus flavus & $0.015-0.5$ & 0.125 & 0.5 & 0.156 \\
\hline & Bipolaris spp. & $0.125-1$ & 0.125 & 0.5 & 0.197 \\
\hline & Exserohilum spp. & $0.03-2$ & 0.12 & 2 & 0.205 \\
\hline & Curvularia spp. & $0-0.25$ & 0.25 & 0.25 & 0.25 \\
\hline & Alternaria spp. & - & - & - & - \\
\hline & Exophiala spp. & - & - & - & - \\
\hline \multirow[t]{8}{*}{ ECN } & Fusarium spp. & $2-8$ & 4 & 8 & 5.401 \\
\hline & Non-sporulating molds & $0.125-4$ & 2 & 4 & 0.85 \\
\hline & Aspergillus flavus & $0.015-0.5$ & 0.5 & 0.5 & 0.248 \\
\hline & Bipolaris spp. & $0.25-1$ & 0.5 & 1 & 0.5 \\
\hline & Exserohilum spp. & $0.06-4$ & 0.06 & 4 & 0.244 \\
\hline & Curvularia spp. & $0-0.5$ & 0.5 & 0.5 & 0.5 \\
\hline & Alternaria spp. & - & - & - & - \\
\hline & Exophiala spp. & - & - & - & - \\
\hline \multirow[t]{8}{*}{ KTZ } & Fusarium spp. & $8-16$ & 16 & 16 & 13.928 \\
\hline & Non-sporulating molds & $0.25-2$ & 1 & 2 & 0.925 \\
\hline & Aspergillus flavus & $0.25-2$ & 2 & 2 & 1.259 \\
\hline & Bipolaris spp. & $0.125-4$ & 0.5 & 1 & 0.629 \\
\hline & Exserohilum spp. & $0.03-8$ & 0.125 & 8 & 0.416 \\
\hline & Curvularia spp. & $1-2$ & 1 & 2 & 1.259 \\
\hline & Alternaria spp. & - & - & - & - \\
\hline & Exophiala spp. & - & - & - & - \\
\hline \multirow[t]{8}{*}{ ITC } & Fusarium spp. & $16-32$ & 32 & 32 & 31.269 \\
\hline & Non-sporulating molds & $0.06-1$ & 1 & 1 & 0.460 \\
\hline & Aspergillus flavus & $0.25-0.5$ & 0.25 & 0.25 & 0.280 \\
\hline & Bipolaris spp. & $0.25-8$ & 0.25 & 0.5 & 0.561 \\
\hline & Exserohilum spp. & $0.06-32$ & 0.06 & 32 & 0.471 \\
\hline & Curvularia spp. & $0.25-0.5$ & 0.5 & 0.5 & 0.396 \\
\hline & Alternaria spp. & - & - & - & - \\
\hline & Exophiala spp. & - & - & - & - \\
\hline \multirow[t]{8}{*}{ VRC } & Fusarium spp. & $1-8$ & 4 & 8 & 4 \\
\hline & Non-sporulating molds & $0.25-8$ & 2 & 8 & 1.851 \\
\hline & Aspergillus flavus & $0.015-0.5$ & 0.125 & 0.125 & 0.110 \\
\hline & Bipolaris spp. & $0.06-4$ & 0.25 & 0.25 & 0.278 \\
\hline & Exserohilum spp. & $0.06-2$ & 0.06 & 2 & 0.205 \\
\hline & Curvularia spp. & $0.125-0.25$ & 0.25 & 0.25 & 0.198 \\
\hline & Alternaria spp. & - & - & - & - \\
\hline & Exophiala spp. & - & - & - & - \\
\hline \multicolumn{6}{|c|}{$\begin{array}{l}\text { MIC: minimum inhibitory concentration; Antifungal agents: CLT: clotrim } \\
\text { voriconazole. } \\
\text { a Interval between the lowest and highest MICs. } \\
\text { b Minimum inhibitory concentration median of the antifungal agent. } \\
\text { c Minimum concentration of the antifungal agent 90th percentile. } \\
\text { d Geometric mean of MICs. }\end{array}$} \\
\hline
\end{tabular}

that Fusarium strains were susceptible to ECN at a lower MIC similar to the reports of Galarreta et al. [12]. The present findings revealed that, Fusarium spp. and Exophiala spp. were resistant to VRC and hence higher concentration of drug is required for the effective treatment. However, there are studies that have suggested that VRC may have a broader antifungal spectrum $[19,20]$. Similar to our findings, Lalitha et al. [17] and lqbal et al. [31] stated that Fusarium spp. had highest MICs to VRC. Prajna et al. [25] reported that monotherapy with topical voriconazole cannot be recommended for filamentous fungal keratitis. Additionally, there are reports of intraocular VRC to be safe in vitro and in vivo and less toxic to the retina than $\mathrm{AMB}[26,13]$. Pfaller et al. [30] reported that ITC exerts negligible activity against Fusarium spp. and it has also been stated that ITC has seldom been administered for Fusarium infections with non-univocal results [38]. 
Our results indicated that higher concentration of ITC and KTZ was required for the inhibition of the involved filamentous fungal isolates, and based on the data obtained, CLT followed by VRC and ECN are the suggested antifungal agents for the first-line therapy of human keratomycoses caused by filamentous species. In addition, this study has generated MIC data for sparingly tested filamentous fungi such as Alternaria spp., Bipolaris spp., Curvularia spp., Exserohilum spp. and Exophiala spp.

\section{Conclusion}

Overall, the determination of MICs of the investigated fiveazole antifungal drugs against the filamentous fungi causing keratitis was useful in understanding the efficacy of increased concentrations of the drugs in inhibiting fungal growth. The present study observed a variation in the overall activity of the azole drugs depending on the type of the fungal species and the drug concentration. Due to the fact that the practice of subjecting fungal isolates to antifungal susceptibility tests is uncommon across the diagnostic microbiology laboratories in India, and that the susceptibility pattern is depending from the involved fungus as well as the nature and concentration of the applied drug, it is further emphasized that the isolates should compulsorily be examined for their susceptibility to ensure an accurate therapy.

\section{Disclosure of interest}

The authors declare that they have no conflicts of interest concerning this article.

\section{Acknowledgment}

The research of M.H., L.G., Cs.V. was supported by the European Union and the State of Hungary, co-financed by the European Social Fund in the framework of TÁMOP 4.2.4.A/2-11-1-2012-0001 "National Excellence Program"'. The relating research groups were also supported by the University Grants Commission (UGC), Bahadur Shah Zafar Marg, New Delhi -110 002, India [F. No. 42-469/2013 (SR)] and the Indo-Hungarian bilateral exchange program no. IA/ INSA-HAS Project/2013-2015/189 providing infrastructure and research equipment.

\section{References}

[1] Agarwal PK, Roy P, Das A, Banerjee A, Maity PK, Banerjee AR. Efficacy of topical and systemic itraconazole as a broad-spectrum antifungal agent in mycotic corneal ulcer. A preliminary study. Indian J Ophthalmol 2001;49:173-6.

[2] Agrawal V, Biswas J, Madhavan HN, Mangat G, Reddy MK, Saini $\mathrm{JS}$, et al. Current perspectives in infectious keratitis. Indian J Opthalmol 1994;42:171-92.

[3] Akter L, Salam MA, Hasan B, Begum N, Ahmed I. Etiological agents of suppurative corneal ulcer: study of 56 cases. Bangladesh J Med Microbiol 2009;3:33-6.

[4] Baginski M, Czub J. Amphotericin B and its new derivatives mode of action. Current Drug Metab 2009;10:459-69.

[5] Bennett JE. Diagnosis and treatment of fungal infections. In: Fauci AS, Braunwald E, Isselbacher KJ, Wilson JD, Martin JB,
Kasper DL, et al., editors. Harrison's principles of International Medicine. New York: McGraw-Hill; 1998. p. 1148-54.

[6] Bharathi MJ, Ramakrishnan R, Vasu S, Meenakshi R, Palaniappan R. Epidemiological characteristics and laboratory diagnosis of fungal keratitis. A three-year study. Indian J Ophthalmol 2003;51: 315-21.

[7] Bharathi MJ, Ramakrishnan R, Meenakshi R, Padmavathy S, Shivakumar C, Srinivasan M. Microbial keratitis in South India: influence of risk factors, climate, and geographical variation. Ophthalmic Epidemiol 2007;14:61-9.

[8] Bharathi MJ, Ramakrishnan R, Meenakshi R, Shivakumar C, Lional Raj D. Analysis of the risk factors predisposing to fungal, bacterial \& Acanthamoeba keratitis in south India. Indian J Med Res 2009;130:749-57.

[9] Clinical Laboratory Standards Institute. Reference method for broth dilution antifungal susceptibility testing of filamentous fungi; approved standard, . 2nd ed., Wayne, PA: Clinical and Laboratory Standards Institute; 2008 [CLSI document M38-A2].

[10] Drummond LJ, McCoubrey J, Smith DG, Starr JM, Poxton IR. Changes in sensitivity patterns to selected antibiotics in Clostridium difficile in geriatric in-patients over an 18-month period. J Med Microbiol 2003;52:259-63.

[11] Forster RK, Rebell G, Wilson LA. Dematiaceous fungal keratitis. Clinical isolates and management. Br J Ophthalmol 1975;59: 372-6.

[12] Galarreta DJ, Tuft SJ, Ramsay A, Dart JK. Fungal keratitis in London: microbiological and clinical evaluation. Cornea 2007; 26:1082-6.

[13] Gao H, Pennesi M, Shah K, Qiao X, Hariprasad SM, Mieler WF, et al. Intravitreal voriconazole: an electroretinographic and histopathologic study. Arch Ophthalmol 2004;122:1687-92.

[14] Harris JL. Safe, low-distortion tape touch method for fungal slide mounts. J Clin Microbiol 2000;38:4683-4.

[15] Homa M, Shobana CS, Singh YRB, Manikandan P, Panneerselvam $\mathrm{K}$, Kredics L, et al. Fusarium keratitis in South India: causative agents, their antifungal susceptibilities and a rapid identification method for the Fusarium solani species complex. Mycoses 2013;56:501-11.

[16] Houang E, Lam D, Fan D, Seal D. Microbial keratitis in Hong Kong: relationship to climate, environment and contact-lens disinfection. Trans R Soc Trop Med Hyg 2001;95:361-7.

[17] Iqbal NJ, Boey A, Park BJ, Brandt ME. Determination of in vitro susceptibility of ocular Fusarium spp. isolates from keratitis cases and comparison of Clinical and Laboratory Standards Institute M38-A2 and E test methods. Diagn Microbiol Infect Dis 2008;62:348-50.

[18] Jacob P, Gopinathan U, Sharma S, Rao GN. Calcium alignate swab versus Bard Parker blade in the diagnosis of microbial keratitis. Cornea 1995;14:360-4.

[19] Lalitha P, Shapiro BL, Srinivasan M, Prajna NV, Acharya NR, Fothergill AW, et al. Antimicrobial susceptibility of Fusarium. Aspergillus, and other filamentous fungi isolated from keratitis. Arch Ophthalmol 2007;125:789-93.

[20] Lalitha P, Sun CQ, Prajna NV, Karpagam R, Geetha M, O’Brien $\mathrm{KS}$, et al. In vitro susceptibility of filamentous fungal isolates from a corneal ulcer clinical trial. Am J Ophthalmol 2014;157: $318-26$.

[21] Laniado-Laborin R, Cabrales-Vargas MN. Amphotericin B: side effects and toxicity. Revista Iberoam Micol 2009;26:223-7.

[22] Leck AK, Thomas PA, Hagan M, Kaliamurthy J, Ackuaku E, John $M$, et al. Etiology of suppurative corneal ulcers in Ghana and south India, and epidemiology of fungal keratitis. $\mathrm{Br} \mathrm{J}$ Ophthalmol 2002;86:1211-5.

[23] Liesegang TJ, Forster RK. Spectrum of microbial keratitis in South Florida. Am J Ophthalmol 1980;90:38-47.

[24] Manikandan P, Varga J, Kocsubé S, Anita R, Revathi R, Vágvölgyi C, et al. Epidemiology of Aspergillus keratitis at a tertiary care 
+ Models

MYCMED-525; No. of Pages 6

6

C.S. Shobana et al.

eye hospital in South India and antifungal susceptibilities of the causative agents. Mycoses 2013;56:26-33.

[25] Marangon FB, Miller D, Giaconi JA, Alfonso EC. In vitro investigation of voriconazole susceptibility for keratitis and endophthalmitis fungal pathogens. Am J Ophthalmol 2004;137: $820-5$.

[26] Nehemy MB, Vasconcelos-Santos DV, Torqueti-Costa L, Magalhes EP. Chronic endophthalmitis due to Verticillium species after cataract surgery treated (or managed) with pars plano vitrectomy and oral and intravitreal voriconazole. Retina 2006; 26:225-7.

[27] Norina TJ, Raihan S, Bakiah S, Ezanee M, Liza-Sharmini AT, Wan Hazzabah WH. Microbial keratitis: etiological diagnosis and clinical features in patients admitted to Hospital Universiti Sain Malaysia. Singapore Med J 2008;49:67-71.

[28] O'Day DM. Fungal keratitis. In: Pepose JS, Holland GN, Withemus KR, editors. Ocular infections and immunity. St Louis: Mossy; 1997. p. 263-4.

[29] O'Day DM, Head WS, Robinson RD, Clanton JA. Corneal peeration of topical amphotericin B and natamycin. Cur Eye Res 1986;5:877-82.

[30] Pfaller MA, Messer SA, Hollis RJ, Jones RN, Diekema DJ. In vitro activities of ravuconazole and voriconazole compared with those of four approved systemic antifungal agents against 6970 clinical isolates of Candida spp. Antimicrob Agents Chemother 2002;46:1723-7.

[31] Prajna NV, Krishnan T, Mascarenhas J, Rajaraman R, Prajna L, Srinivasan $M$, et al. The mycotic ulcer treatment trial: randomize trial comparing natamycin vs voriconazole. JAMA Ophthalmol 2013;131:422-9.

[32] Pujol I, Guarro J, Gené J, Gala J. In vitro antifungal susceptibility of clinical and environmental Fusarium spp. strains. J Antimicrob Chemother 1997;39:163-7.
[33] Rosa RH, Miller D, Alfonso EC. The changing spectrum of fungal keratitis in south Florida. Ophthalmology 1994;101:1005-13.

[34] Sirikul T, Prabriputaloong T, Smathivat A, Chuck RS, Yongthongsri A. Predisposing factors and etiologic diagnosis of ulcerative keratitis. Cornea 2008;27:283-7.

[35] Srinivasan M. Fungal keratitis. Gur Opin Ophthalmol 2004; 15:321-7.

[36] Srinivasan M, Gonzales CA, George C, Cevallos V, Mascarenhas JM, Asokan B, et al. Epidemiology and etiological diagnosis of corneal ulceration in Madurai, South India. Br J Ophthalmol 1997;81:965-71.

[37] Srinivasan M, Gonzales CA, George C, Cevallos V, Mascarenhas JM, Asoka B, et al. Epidemiology and etiological diagnosis of corneal ulceration in Madurai, south India. Br J Ophthalmol 1997;81:965-71.

[38] Stanzani M, Tumietto F, Vianelli N, Baccarani M. Uptate on the treatment of disseminated fusariosis: Focus on voriconazole. Then Chin Risk Manas 2007;3:1165-73.

[39] Thomas PA. Mycotic keratitis - an underestimated mycosis. J Med Vet Mycol 1994;32:235-56.

[40] Thomas PA. Current perspectives on ophthalmic mycoses. Clin Microbiobiol Rev 2003;16:730-97.

[41] Tilak R, Singh A, Maurya OP, Chandra A, Tilak V, Gulati AK. Mycotic keratitis in India: a five-year retrospective study. J Infect Der Cries 2010;4:171-4.

[42] Whitcher JP, Srinivasan M, Upadhyay MP. Microbial keratitis. In: Johnson GJ, Minassian DC, Whale RA, West SK, editors. The epidemiology of eye diseases. . Ind ed., London: Arnold; 2003. p. 190-5.

[43] Xe L, Zhai H, Zhao J, Sun S, Ski W, Dong X. Antifungal susceptibility for common pathogens of fungal keratitis in Shandong Province, China. Am J Ophthalmol 2008;146: $260-5$.

Please cite this article in press as: Shobana CS, et al. In vito susceptibility of filamentous fungi from mycotic keratitis to azole drugs.

Journal De Mycologie Médicale (2014), http://dx.doi.org/10.1016/j.mycmed.2014.10.024 